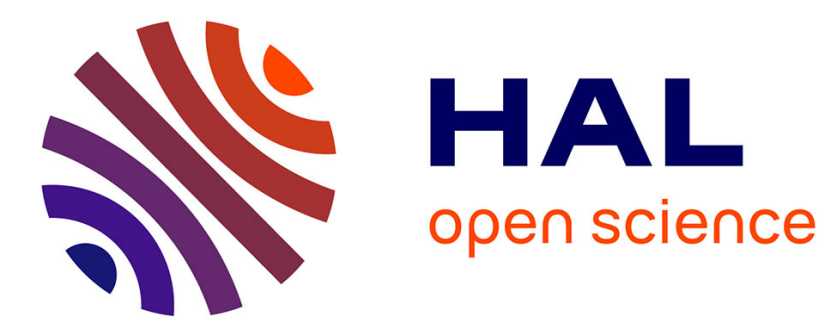

\title{
Researching and marketing to consumption collectives
}

Matthew Hawkins

\section{To cite this version:}

Matthew Hawkins. Researching and marketing to consumption collectives. International Journal of Market Research, 2018, 60 (5), pp.517-530. 10.1177/1470785318769594 . hal-01809954

\section{HAL Id: hal-01809954 https://hal.science/hal-01809954}

Submitted on 13 Jun 2018

HAL is a multi-disciplinary open access archive for the deposit and dissemination of scientific research documents, whether they are published or not. The documents may come from teaching and research institutions in France or abroad, or from public or private research centers.
L'archive ouverte pluridisciplinaire HAL, est destinée au dépôt et à la diffusion de documents scientifiques de niveau recherche, publiés ou non, émanant des établissements d'enseignement et de recherche français ou étrangers, des laboratoires publics ou privés. 


\title{
Researching and marketing to consumption collectives
}

\author{
Matthew A. Hawkins ${ }^{1}$
}

Consumer researchers have identified a handful of consumption collectives, such as consumption tribes, brand communities, and communities of practice. A consumption collective is a group of consumers who share consumption characteristics. Despite the use of participant screens in other research domains, published consumption collective research rarely reports on participant screens demonstrating their participants are actual members of the specific collective under investigation. Without participant screens researchers may mistakenly attribute conflicts over heterogeneous resources to intra-collective competition when the source may be inter-collective competition. This research demonstrates that consumer researchers can implement a short survey during field interviews as a participant screen. The article concludes by suggesting that marketing strategies and branding messages should be adjusted according to the individual consumer's consumption collective membership status.

\section{Introduction}

Consumer researchers have identified a handful of consumption collectives, such as consumption tribes (Cova 1997), brand communities (Muñiz \& O'Guinn 2001), and communities of practice (Leigh et al. 2006). A consumption collective is an umbrella term applied to a group of consumers "who share a commitment to a product class, brand, activity, or consumption ideology" (Thomas et al. 2013: 1012). Extant studies typically focus on understanding how specific collectives form (McAlexander et al. 2002) and how being a member of a collective impacts consumers' meaning-making processes (Kates 2002). While understanding that multiple consumption collectives exist researchers rarely conduct and report participant screens demonstrating their participants are actual members of the specific collective under investigation. This is surprising as participant screens are commonly implemented in other research domains and in the consulting and private realms. Participant screens are questions directed to the interviewee to ensure they meet the requirements to be included in the study. The lack of

\footnotetext{
${ }^{1}$ Matthew A. Hawkins, matthew.hawkins@icn-artem.com, ICN Business School, University of Lorraine - CEREFIGE
} 
participant screens is problematic as researchers are beginning to argue that despite sharing consumption patterns, consumers' divergent goals and use of heterogeneous resources create tensions that impact intra-collective relationships (Leigh et al. 2006; Thomas et al. 2013). Without participant screens researchers may mistakenly attribute conflicts over heterogeneous resources to intra-collective competition when the source may be inter-collective competition.

For marketers, understanding whether a group of consumers are a consumption collective can help in determining what type of marketing strategy to implement. This is because members of a consumption collective are interested in the meaning-making process surrounding the brand and the activities it is used within. Conversely, non-members tend to have transactional relationships with the brand. Thus, implementing community marketing strategies with nonmembers may waste resources and instead community strategies should target collective members.

Accordingly, this research has two goals (1) to demonstrate that consumption collective researchers can implement a short field survey as a participant screen and (2) to propose that marketers adjust their marketing strategies and branding messages according to the consumer's consumption collective membership status. A motorcycle rally serves as the empirical setting for discussing the practicality of implementing participant screens. This four-day event is an ideal setting as it routinely attracts over a quarter-million visitors (Stigar 2013) or potential consumption collectives members.

This research makes multiple contributions. Methodologically, it affirms that consumer researchers can implement participant screens in the field to demonstrate participants are part of the specific collective under investigation. Future research can take advantage of implementing participant screens longitudinally to explore how membership status transforms through time. Managerially, it is argued that marketers should implement transactional marketing strategies to consumers not involved in a collective while community marketing strategies are more appropriate for consumers who are members of a collective.

\section{Site: Bikes, Blues \& BBQ}

The Bikes, Blues \& BBQ (BBB) motorcycle rally held in Fayetteville, Arkansas served as the empirical setting. This geo-temporal event was purposely selected because this event is not supported by a brand, such as in brand fests (McAlexander et al. 2002). In fact, substantial 
diversity in the types of businesses and brands participating in the event was evident. Ample space was dedicated to motorcycle manufacturers, customizers, part suppliers, and even a test riding course; and, there were numerous food and craft vendors, local community organizations, beer gardens, and a music stage. Additionally, the event is embraced by both the city and the community and is free of charge. Because BBB attracts a wide range of consumers interested in motorcycles more generally it is an ideal site to interact with potential members of brand communities, consumption tribes, and communities of practice.

In fact, some attendees had limited interest in motorcycles rather they attended the event to execute transactions in the temporary marketplace. For example, one young couple interviewed on Saturday night came to purchase pulled-pork sandwiches from an award winning vendor they heard about on the internet and to look at the bikes. Accordingly, a portion of the attendees never became community members as they lacked a "sense of duty or obligation to the community as a whole, and to its members" (Muñiz \& O'Guinn 2001: 413). In essence, some consumers interacted with the event as a stable entity and were unaware of or uninterested in the social status games being played by the various consumption collectives present at the event.

\section{Methods: field research}

The field research included conducting formal $(\mathrm{n}=12)$ and informal $(\mathrm{n}=15)$ interviews with BBB attendees. The formal interviews involved following a semi-structured interview protocol and providing a short self-administered survey which served as the participant screen (see Appendix). The formal interviews focused on understanding the consumer's experience at BBB as well capturing descriptions of their motorcycle, riding preferences, riding attire, and their overall motorcycle consumption habits. Interviews that followed the protocol but did not result in the screen being administered are classified as an informal interview. Additionally, the normal social interactions and discussions that occur at an event were classified as informal interviews.

The field research utilized a wide-range of data collection methods: pocket audio recorder (15hrs, 39mins), wearable ear-mounted video camera (7hrs, 00mins), handheld video camera (1hr, 52mins) and a digital still camera (281 photos) to capture the majority of the interviews and event participation. Multiple special events were attended, such as portions of the Battle of the Bikes, a bike judging contest, and the Parade of Power (Figure 1), a multi-hour stream of bikers 
riding down Dickson, the city's main street. I also rode my moped up and down the main street a few times each day to visually capture and experience this conspicuous display ritual.

\section{Insert Figure 1 about here}

All recorded formal and informal interviews were transcribed. Drawing on extant research and using the consumption collective typologies developed by Canniford (2011), Goulding and colleagues (2013) and Thomas and colleagues (2013) participants were categorized into their appropriate consumption collective based on the interview transcript. A few participants were not placed into a pre-existing consumption collective category and instead they were classified as market participants. This is because their interviews suggest their attendance was motivated by the opportunity to take advantage of BBB for traditional market reasons, such as purchasing food, enjoying the music, or otherwise engaging in transactional relationships with BBB vendors and organizations. After each participant was categorized the participant screens were visually inspected to determine if their survey results correspond with their discourse.

\section{Participant screen}

Participant screens are questions administered to interviewees to ensure they fit the characteristics of the study's desired participants and/or demonstrate they possess certain characteristics. They tend to be categorical (sex, party affiliation) when tied to study participant requirements. The failure to report and even collect evidence supporting membership claims can be problematic as screens help ensure the study is researching what it intends to research.

Thomas, Price, and Schau (2013), for instance, explore community tensions, arguing that "heterogeneity and resource dependence co-occur and are intertwined such that the community sustains itself by building a network of dependent social and economic resource exchanges between heterogeneous actors" (p. 1017). Thus, the competition within a community creates the social structure allowing for differing levels of social capital to be distributed. Social capital is akin to economic capital with one major distinction: social capital functions within social relations while economic capital functions with economic or monetary relations (Bourdieu 1990). Thus, social capital is only a resource within specific social arrangements, groups or collectives. Demonstrating or displaying one's social capital helps position the individual within the 
collective and, ultimately, determines their identity (Arsel \& Thompson 2011; Bourdieu 1984). Accordingly, understanding the social rules or structuralized behaviour patterns regrading what body movements to (not) make, what objects (not) to possess and what words to (not) say have important ramifications on an individual's ability to accrue social capital as well as constructing their identity.

This competitive social game provides meaning to members by offering them something to be engaged in and helping them develop a sense of belonging. However, while Thomas and colleagues (2013) assert "belonging refers to the degree to which communities embrace solidarity and togetherness (communitas) as a part of their collective identity" (p. 1012), Thomas and colleagues do not provide any evidence that their informants possess solidarity or a collective identity with other members. In fact, the presented data demonstrate the opposite. An informant named Ryan stated "If you are going to run or walk a marathon, just go walk [26 miles] yourself. Don't waste everyone else's time, getting in front of everyone and slowing down...elite runners" (p. 1020). Ryan's other passage is just as disparaging. While Thomas et al. (2013) interpret this statement as a source of intra-community tension it may have been inter-collective or inter-group tension as Ryan appears to be placing himself in the elite runner community thereby distancing himself from the running tribe. This example demonstrates that reporting on why each participant was classified as a community member can bolster claims that intra-community tension is not actually inter-collective tension.

Individuals are members of multiple collectives, groups and communities. They may feel connected to others who engage in the same profession, share interest in a particular clothing or motorcycle brand or enjoy a certain leisure activity, for instance. An individual's behaviors, discourse and mindset are motivated not just by their social relations but also their social setting (Allen 2002). While individuals may spend more time within one community over another, multimembership is not hierarchical, like a pyramid but, instead, interconnected, like a web (Warde 2014). Accordingly, it is necessary to triangulate not just the research phenomena but also informant's membership or identity. Implementing participant screens within the field can help justify informant status because they were interviewed within the social setting where the specific membership is activated and their corresponding mindset is surveyed. 
The next section reviews three main consumption collectives and presents representative participant screens collected in the field. The purpose of this section is to demonstrate that consumption collective research can implement a simple participant screen in the field.

\section{Types of consumption collectives}

\section{Brand community}

Brand communities arise when social relationships develop among brand admirers to enhance consumption experiences (McAlexander et al. 2002). The resulting strong consumer-brand relationship encourages members to expend substantial personal resources or "go the extra mile" to show their support for the brand. This involves more than just higher rates of spreading positive word-of-mouth or repeat purchasing to include traveling great distances to attend corporate sponsored events and wearing branded clothing (Bhattacharya \& Sen 2003; Marzocchi et al. 2013). What distinguishes brand community members from brand loyal consumers is they have not only have a deep connection with the brand but also with other brand users and have a desire to protect and support community members. Accordingly, research participants must possess the three markers of community "shared consciousness, rituals and traditions, and a sense of moral responsibility" (Muñiz \& O'Guinn 2001: 412) to be classified as brand community members. Otherwise they are brand loyal consumers or even a brand champions but they are not brand community members.

As an example, consider Jim a CPA from Utah, who first flew with his motorcycle to Harley-Davidson's headquarters in Milwaukee, Wisconsin for their $110^{\text {th }}$ Year anniversary before riding over 700 miles with his brother to BBB. Unlike his brother, Jim wasn't wearing a HarleyDavidson branded t-shirt and bandana; rather, he was smart looking in jeans, yellow baseball cap, and a long sleeve t-shirt - a quintessential RUB (Rich Urban Biker). In fact he was practically called out as such on this trip:

Jim - We pulled into Milwaukee and my brother, John, was standing there and there was a guy on an old, you know, kind of original Harley, and...I mean the hard-core and he sees me pull in next to John. And he turns to John and...well he turns next to him and says to himself... What did he say? 
John - "They will sell these damn things to anybody". Meaning he recognized he was not like him. The guys like him are the only ones that really should be riding these bikes.

Jim's experience exemplifies both the positives and negatives of brand communities. $\mathrm{He}$ is definitely a Harley-Davidson brand champion who encourages others to purchase the brand and travels great distances to support the brand and to meet other brand enthusiasts. However, conflicts over authentic performances appear to deter some brand users from developing a shared moral responsibility with other brand users. Without a participant screen researchers may have mistaken Jim for a brand community member.

Participant screens for brand community members need to take into consideration the three markers of community membership as well as a desire to support the brand. Therefore, this study expected to see high ratings for participants' consumer-brand connection as well as their communal-brand connection, customer commitment, and intentions to spread positive word-ofmouth. The latter scales serve as a proxy for a shared sense of moral responsibility and consciousness. However, Figure 2 provides Jim's raw participant screen data which finds that he has a reduced connection with fellow brand users and he doesn't fully believe other users are like him. Thus, he may not be brand community member or there may be multiple Harley-Davidson brand communities.

\section{Insert Figure 2 about here}

\section{Consumption tribes}

Consumption tribes are groups of consumers engaged in similar activities and characterized by their focus on social interaction and play (Cova 1997). Tribal membership is often multiple, resulting in a liquid boundary that emerges, adjusts, and dissipates sometimes as fast as it arrives (Canniford 2011). Tribes negotiate and share meaning as other collectives but often change, combine, and create new meanings in innovative ways to meet their specific interests. Therefore, the presence of legitimacy markers stemming from structuralized behavior patterns, such as wearing appropriate clothing are reduced, if present at all. Further, hierarchical structures are less common in tribes as they are organic in growth and tend to spontaneously arise due to a collective emotional state (Cova et al. 2007; Goulding et al. 2013). Thus, to consumption tribes, 
brands are valued for the social-linking value over functional value because using a brand facilitates social interaction which is different than brand community members who value a brand and then form relationships with others because they use the brand. Participant screens for consumption tribe members do not require high intentions to spread positive word-of-mouth or high levels of brand commitment. This is because the consumer's consumption experience revolves around social interaction and not maintaining a relationship with the brand, as is the case with brand community members. While some consumers may have elevated relationships with the brand, if a participant evidences high commitments or attachments to other brand users this may suggest they are a brand community member and extra attention should be given to their interview transcripts.

Figure 3 presents Bob's participant screen. Bob rode to BBB with his wife to reunite with another couple he met earlier in Indiana while working as a pig hauler. Prior to administering the participant screen, his response to what bikes he likes suggests he is not a Harley-Davison brand community member, even though Harley is his favorite motorcycle brand and he owns one.

Bob - "I like them all really. I am not a hard-core Harley man like some around here. I will still ride. I will ride anything. I enjoy being with people who will ride anything. I checked out the new Indians over there, at the University. They are beautiful."

\section{Insert Figure 3 about here}

Accordingly, consumption tribe members' consumption experiences are characterized by a preference for social interactions and the brands enrolled into consumption experiences tend to have lower prominence than in brand community members. Resource play and creative arrangements may then be mischaracterized as conflict over authentic performance or a social status game when in fact tribes lack the social structure necessary for resource competition. There is no legitimate or correct way to perform for consumption tribe members while brand communities have a social structure coming from their shared history and way of doing things. Understanding whether a consumer is playing or competing with their resource configurations is, therefore, key in identifying whether a consumer is a consumption tribe member or brand community member. 


\section{Communities of practice}

The identifiable consumption patterns of a community of practice are not a direct result of an intention to consume a specific product or brand, as in brand communities or engage in social interaction, as in consumption tribes. Rather, communities of practice predominately focus their attention towards practice enactment, improvement, and preservation (Lave \& Wenger 1991; Wenger 2000). Communities of practice develop through a shared understanding of how an activity should be done (Bourdieu 1990). Communities of practice do not need to possess hierarchical structures but formal communities of practice, commonly referred to as a trade or professional association often have structured hierarchies. Communities of practice possess a sense of mutuality: the belief that involvement in a community helps them do an activity better than not self-organizing. Organization researchers have predominately explored how communities of practice share knowledge and how they coordinate with outsiders (Carlile 2002). Similarly, consumer researchers often look at how meanings or values are managed within communities of practice (Leigh et al. 2006).

In terms of participant screening, both the interview script and survey included questions to capture if motorcycles are a component of the interviewee's profession. A prominent community of practice evident in the data was the mechanical community. The following introduces Tommy who hand-builds one-of-a-kind bikes that are products of his imagination and creative process (Figure 4). He values the construction process because it allows him to test his skills and improve his competency, as he often builds things because "I just wanted to see if I could do it".

\section{Insert Figure 4 about here}

It is quite evident that Tommy is not deeply concerned with promoting his self-selected favorite motorcycle brand, Harley-Davidson (See Figure 5); rather, he is focused on enacting the mechanical practice. He has built bikes for all of his six boys and is currently working on a couple of their girlfriends' bikes. Moreover, on Saturday he spent the day sitting next to James who had the only hand-built Rat Bike at the rally. They met the preceding year at BBB when they were interviewed for the news. While both Tommy and James are very friendly and open they 
didn't initiate social interaction with event attendees or wear Harley-Davidson attire. Accordingly, consumption patterns emerging from communities of practice place prominence on enacting and preserving the practice, in this case the mechanical practice over the brands they may use in the practice.

\section{Insert Figure 5 about here}

\section{Summary}

This section demonstrated that qualitative researchers can implement a brief self-administered survey as a participant screen. This study used existing scales but researchers should construct a participant screen that meets their needs. Without a participant screen researchers may mistakenly classify participants as members of a particular consumption collective or misinterpret tensions and conflicts over object authenticity, for instance, as an intra-collective conflict when the tensions over what counts as an authentic object may be better explained as an inter-collective conflict.

\section{Marketing to consumption collective members}

While this study focuses on consumption collective members, it is important to address consumers who are not collective members. First, collective-like practices are evident in members of a collective who engage in social status games by contesting, negotiating and altering the meanings of resources within the collective (Levina \& Vaast 2006). In essence, these individuals are attempting to accrue social capital by demonstrating an understanding of the collective's rules (Bourdieu 1984). Collective-like practices not only include behaviors that place themselves within the collective's hierarchy but also behaviors that attempt to change what counts as a legitimate community behavior. Leigh and colleagues' (2006) work on what counts as an authentic MG highlights some of the intra-collective conflicts that can arise when members challenge the meanings attributed to objects. Kates (2002) work on joining the gay community, illustrates the process of joining a community. His work shows that individuals, when entering a community, tend to mimic others. Then, as they gain knowledge and confidence in their ability to work within the social structure they begin to challenge accepted symbolic meanings and behaviors in an effort to carve out a unique identity within the community. 
Consumers interested in joining the collective have legitimate peripheral membership (Lave \& Wenger 1991; Wenger 2000), until they have the ability to fully participate in the collective. Accordingly, legitimate peripheral practices are reserved for consumers who are legitimately able to participate in the collective's activities but have low social capital and are developing their understanding of the collective's norms and shared history. Accordingly, peripheral collective members do not have the social capital to fully engage in meaning altering games but are interested in these intra-collective conflicts nonetheless (Bourdieu 1990). Thus, peripheral members enact a mix of collective-like practices and market-like practices. Marketlike practices are evident in consumers who accept the meaning of a resource as objectively established (Levina \& Vaast 2006). This is different from legitimate peripheral practices, where a consumer is attempting to enter a collective through gradually learning the required behaviors and discourse and is actively engaging in intra-collective meaning making. In essence, consumers enact market-like practice when they are uninterested in the social games or resource conflicts occurring around them and are, therefore, not members of the collective under investigation.

\section{Insert Figure 6 about here}

Classifying consumer by collective membership status suggests that differing marketing strategies might be more appropriate depending on the membership status of the consumer being targeted (see Figure 6). Consumers engaging in market-like practices are interested in taking the values embedded into the brand and incorporating them into their life projects. They are not interested in actively participating in its meaning creation system. Therefore, transactional marketing could be a particularly efficient strategy to implement when targeting consumers not part of a consumption collective. However, brand managers should still develop a clear brand image within the market so consumers can integrate the branded resource into their lives. Even though consumers do not collaborate with a brand this does not negate the fact that the brand is being integrated into their social system (Vargo \& Lusch 2008), has symbolic meaning in their life and should be managed accordingly.

As peripheral participants are actively engaging with a collective and are trying to acquire the capital and knowledge necessary to become a legitimate member of the collective offering them support could be advantageous. Moreover, they are becoming familiar with a brand's 
functional quality and values presenting an opportune time to strength the consumer-brand link by implementing relationship marketing strategies. This is important for brand managers as brand community members have higher repurchase tendencies compared to consumption tribe members who are more prone to switch brands in order to maintain social relations as they have lower brand commitment levels. Additionally, strengthening the consumer-brand relationship in this stage may motivate these consumers to join a brand community over a community of practice, for instance.

Members of a collective are actively involved in the meaning management process and are characterized by their desire to preserve the collective's prominent resource, whether it is a practice or a brand. Accordingly, brand managers should consider implementing community marketing strategies to collective members. First, creating opportunities for consumers to meet and share knowledge can help facilitate the formation of a community (McAlexander et al. 2002; Wenger \& Snyder 2000). Besides supporting social relation development, meeting others enables consumers to enhance their self-esteem through demonstrating their competency in using the brand and brand knowledge, more generally (Schau et al. 2009). Thus, brand focused social events can subtly direct a collective's interest towards brand preservation in an effort to form a brand community. Additionally, developing a connection with these consumers can help identify trends and new products as they tend to be generated by heavy end-users interested in personalizing and modifying products (Roberts \& Darler 2017; von Hippel 2005).

Schau and colleagues (2009) further suggest that vibrant communities display a series of practices that can be classified into four main categories. Accordingly, brand managers interested in implementing a community marketing strategy should ensure that their consumers have sufficient social networking opportunities. Interested members need to be welcomed, they need to feel as if they are supported and cared about, have a set of rules to follow and be provided with opportunities to transition from a peripheral member into a full member. The community also needs to possess impression management practices. These practices or activities evangelize, promote or otherwise encourage others to join and these practices also justify the community's existence by defending it and other members from negative images or discourse. Successful communities are also composed of members who evidence community engagement practices. Specifically, members often strive for and highlight the achievement of significant events. For example, Schau and colleagues (2009) note that concert-goers often celebrate their $100^{\text {th }}$ show or, 
as this study's informant Jim mentioned, visiting the brand's headquarters. Members also stake claims to or become experts in specific domains within the community. This feature enables members to develop a unique identity based on community-valued knowledge while still fitting in or maintaining a sense of belonging. The last set of practices a vibrant brand community possesses is brand use. In particular, communities share and promote a specific usage or consumption pattern. They also modify and customize the brand to meet their needs. Lastly, communities generate or produce innovative brand related objects and material. Brand managers are urged to identity which practices are underdeveloped within a collective and then develop a strategy to develop this practice, such as sending welcome letters, suggesting milestones, and supporting product modifications.

\section{Summary}

This research demonstrates that researchers focused on consumption collective membership should consider implementing short participant screens to ensure participants are part of the group or collective under investigation. Currently, while common in private practice and in other research domains, research on consumption collectives rarely justify their informants' membership status. In fact, the author is unaware of any published study in which researchers explicitly state how each informant met the requirements to be classified as a brand community member, for instance.

This is potentially problematic as research interest is moving away from justifying the presence of various consumption collectives to understanding how intra-collective conflicts impact the meaning making process and develop various forms of social capital using heterogeneous resources. Therefore, it is suggested that consumption collective researchers should implement and report on participant screens, especially when membership issues are intertwined with research objectives.

Additionally, developing a participant screen could be advantageous for investigating how and why consumption collective membership transform over time. Research on consumption tribes suggest that tribe members sometimes fall into a routine, using the same brand during multiple social interactions, potentially facilitating their transformation into a brand community member. Additionally, brand community research suggests that members form social relations with other members that center on other activities, potentially weakening brand community 
membership. Longitudinal research is needed to fully understand how consumers transform through time. Is there a standard progression of moving from a consumption tribe to brand community member, for instance? Does the transformation process differ for consumption behaviors that allow for competency improvements? For example, personally restoring a motorcycle provides a consumer with opportunities to not only improve brand knowledge but also their mechanical competency. Thus, the consumer may transform into a community of practice member and not a brand community member if they find more satisfaction or social capital gains in the mechanical community than the brand community. It is recommended to implement relationship marketing and then community marketing to encourage consumers to form a relationship with the brand over the practice or usage activity. Moreover, a multitude of scales exist that measure consumers' resource-identity strength, such as consumer-brand (Escalas \& Bettman 2005), consumer-possession (Ferraro et al. 2011), and consumer-organization (Mael \& Ashforth 1992). Consumers can, potentially, form a relationship with any of these resources and researchers should select the scales that are appropriate for their research question. Accordingly, integrating participant screens into longitudinal studies opens the door for tracing membership transformation through time.

\section{Conclusion}

Consumer researchers have identified and investigated a handful of consumption collectives, such as consumption tribes, brand communities, and communities of practice. This research demonstrates that consumption collective researchers can implement a short survey during field interviews as a participant screen in order to substantiate membership classifications claims. Lastly, marketers are encouraged to adjust marketing strategies and messages based on the individual consumer's consumption collective membership status. 


\section{References}

Allen, D. E. (2002). Toward a theory of consumer choice as sociohistorically shaped practical experience: the fits-like-a-glove (FLAG) framework. Journal of Consumer Research, (28), pp. 512-532.

Arsel, Z., \& Thompson, C. J. (2010). Demythologizing consumption practices: how consumers protect their field-dependent identity investments from devaluing marketplace myths. Journal of Consumer Research, 37, pp. 791-806.

Bhattacharya, C. B., \& Sen, S. (2003). Consumer-company identification: a framework for understanding consumers' relationships with companies. Journal of Marketing, 67, pp. 7688.

Bourdieu, P. (1984). Distinction: A social critique of the judgement of taste. Cambridge, MA: Harvard University Press.

Bourdieu, P. (1990). The logic of practice. Stanford, CA: Stanford University Press. Canniford, R. (2011). A typology of consumption communities. In R. Belk, K. Grayson, A. M. Muñiz, Jr. \& H. J. Schau (Eds.), Research in consumer behavior (Vol 13). (pp. 57-75). Bingley, UK: Emerald.

Carlile, P. R. (2002). A pragmatic view of knowledge and boundaries: boundary objects in new product development. Organization Science, 13, pp. 442-455.

Cova, B. (1997). Community and consumption: towards a definition of the "linking value" of product or services. European Journal of Marketing, 31, pp. 297-316.

Cova, B., Kozinets, R. V., \& Shankar, A. (2007). Tribes, inc.: the new world of tribalism. In B. Cova, R. V. Kozinets \& A. Shankar (Eds.), Consumer tribes (pp. 3-26). Burlington, MA: Butterworth-Heinemann.

Escalas, J. E., \& Bettman, J. R. (2005). Self-construal, reference groups, and brand meaning. Journal of Consumer Research, 32, pp. 378-389.

Ferraro, R., Escalas, J. E., \& Bettman, J. R. (2011). Our possessions, our selves: domains of selfworth and the possession-self link. Journal of Consumer Psychology, 21, pp. 169-177.

Goulding, C., Shankar, A., \& Canniford, R. (2013). Learning to be tribal: facilitating the formation of consumer tribes. European Journal of Marketing, 47, pp. 813-832. 
Kates, S. M. (2002). The protean quality of subcultural consumption: an ethnographic account of gay consumers. Journal of Consumer Research, 29, pp. 383-399.

Lave, J., \& Wenger, E. (1991). Situated learning: Legitimate peripheral participation. Cambridge, MA: Cambridge University Press.

Leigh, T. W., Peters, C., \& Shelton, J. (2006). The consumer quest for authenticity: the multiplicity of meanings within the MG subculture of consumption. Journal of the Academy of Marketing Science, 34, pp. 481-493.

Levina, N., \& Vaast, E. (2006). Turning a community into a market: a practice perspective on information technology use in boundary spanning. Journal of Management Information Systems, 22, pp. 13-37.

Lloyd, A., \& Luk, S. (2011). Interaction behaviors leading to comfort in the service encounter. Journal of Services Marketing, 25, pp. 176-189.

Mael, F., \& Ashforth, B. E. (1992). Alumni and their alma mater: a partial test of the reformulated model of organizational identification. Journal of Organizational Behavior, 13, pp. 103-123.

Marzocchi, G., Morandin, G., \& Bergami, M. (2013). Brand communities: loyal to the community or the brand? European Journal of Marketing, 47, pp. 93-114.

McAlexander, J. H., Schouten, J. W., \& Koenig, H. F. (2002). Building brand community. Journal of Marketing, 66, pp. 38-54.

Muñiz, Jr. A. M., \& O’Guinn, T. C. (2001). Brand community. Journal of Consumer Research, 27, pp. 412-432.

Palmatier, R., Jarvis, C., Bechkoff, J., \& Kardes, F. (2009). The role of customer gratitude in relationship marketing. Journal of Marketing, 73, pp. 1-18.

Park, C. W., MacInnis, D. J., Priester, J. R., Eisingerich, A. E., \& Iacobucci, D. (2010). Brand attachment and brand attitude strength: conceptual and empirical differentiation of two critical brand equity drivers. Journal of Marketing, 74, pp. 16-10.

Roberts, D. L., \& Darler, W. (2017). Consumer co-creation: an opportunity to humanise the new product development process. International Journal of Market Research, 59, pp. 13-33.

Schau, H. J., Muñiz Jr, A. M., \& Arnould, E. J. (2009). How brand community practices create value. Journal of Marketing, 73, pp. 30-51.Schouten, J. W., \& McAlexander, J. H. (1995). 
Subcultures of consumption: an ethnography of the new bikers. Journal of Consumer Research, 22, pp. 43-61.

Stigar, K. (2013, September 18). Fayetteville braces for Bikes, Blues \& BBQ: more than 250,000 visitors expected at festival. The Arkansas Traveler.

Thomas, T. C., Price, L. L., \& Schau, H. J. (2013). When differences unite: resource dependence in heterogeneous consumption communities. Journal of Consumer Research, 39, pp. 10101033.

Thomson, M., MacInnis, D. J., \& Park, C. W. (2005). The ties that bind: measuring the strength of consumers' emotional attachments to brands. Journal of Consumer Psychology, 15, pp. 77-91.

Vargo, S. L., \& Lusch, R. F. (2008). Service-dominant logic: continuing the evolution. Journal of the Academy of Marketing Science, 36, pp. 1-10.von Hippel, E. (2005). Democratizing innovation. Cambridge, MA: The MIT Press.

Warde, A. (2014). After taste: culture, consumption and theories of practice. Journal of Consumer Culture, (14), pp. 279-303.

Wenger, E. C. (2000). Communities of practice and social learning systems. Organization, 7, pp. 225-246.

Wenger, E. C., \& Snyder, W. (2000). Communities of practice: the organizational frontier. Harvard Business Review, (Jan-Feb), pp. 139-145. 


\section{Appendix}

Scales and sources included in participant screen.

Consumer-Brand Connection (Park et al. 2010)

- This brand is part of you and who you are?

- I feel personally connected to the brand?

Brand Prominence (Park et al. 2010)

- My thoughts and feelings toward the brand often automatic, coming to mind seemingly on their own?

- My thoughts and feelings toward the brand come to me naturally and instantly?

Communal-brand connection (Thomson et al. 2005)

- I really identify with people who use this brand.

- This brand is used by people like me.

- I feel a deep connection with others who use this brand.

Customer commitment (Palmatier et al. 2009)

- I am willing "to go the extra mile" to work with this brand.

- I have a desire to maintain my relationship with the brand.

- I view the relationship with this brand as a long-term relationship

Intention to Spread Positive Word-of-Mouth (Lloyd \& Luk 2011)

- I would say positive things about this brand to other people.

- I would recommend this brand to someone who seeks my advice.

- I would encourage friends and relative to do business with this brand.

All scales where measured using a 7-point, labeled, likert-scale: 1=Totally Disagree; 2=Disagree; 3=Somewhat Disagree; 4=Neither Agree or Disagree; 5=Somewhat Agree; 6=Agree; 7=Totally Agree 


\section{List of Figures}

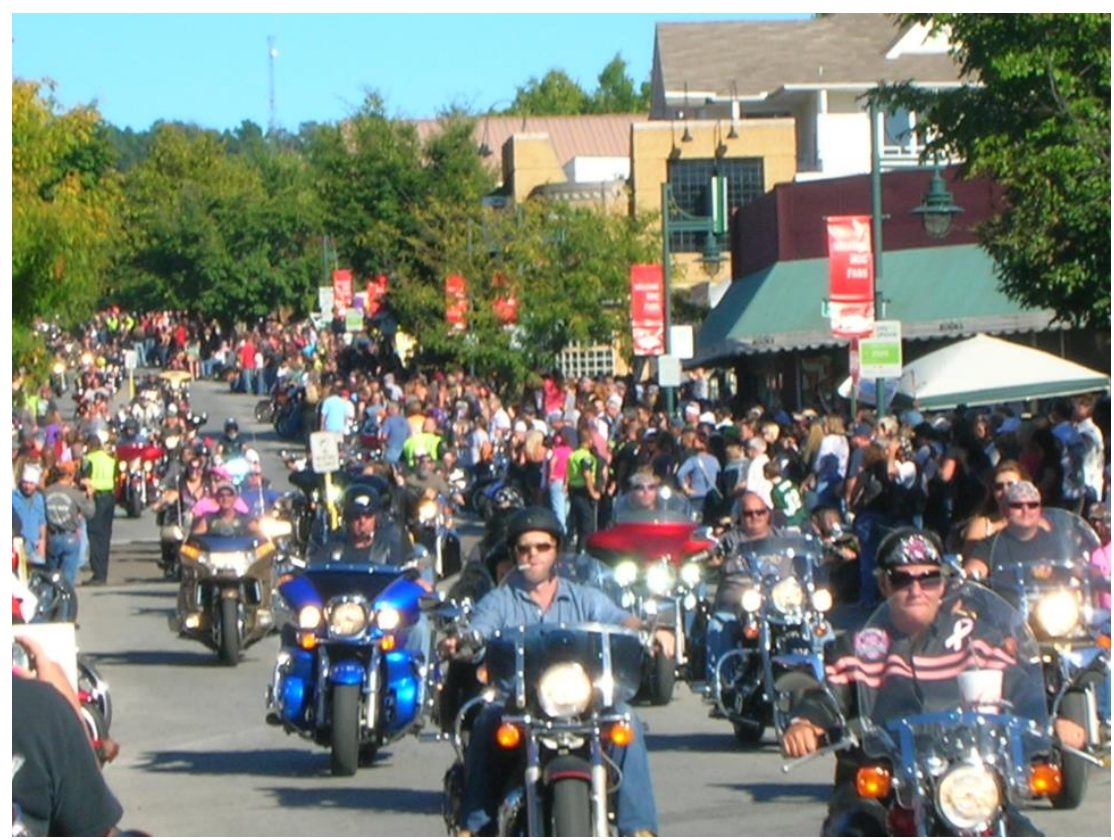

Figure 1 Parade of Power

Approximately how many hours do you ride a motorcycle a week? 5

Approximately, how many hours do you work on your motorcycle(s) a month? _

Roughly, what percentage of your friends have motorcycles? $10 \%$

Does your job involve motorcycles? Yes No

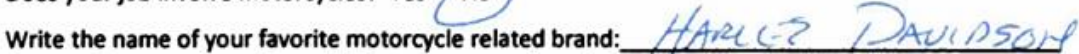

Answer these next questions thinking about your favorite motorcycle related brand.

\begin{tabular}{|c|c|c|c|c|c|c|c|c|}
\hline & & $\begin{array}{l}\text { Totally } \\
\text { Dtsagree }\end{array}$ & Dlsagree & $\begin{array}{c}\text { Somewhat } \\
\text { Disagree }\end{array}$ & $\begin{array}{l}\text { Nelther } \\
\text { Agree or } \\
\text { Disagree }\end{array}$ & $\begin{array}{c}\text { Somewhat } \\
\text { Agree }\end{array}$ & Agree & $\begin{array}{r}\text { Totally } \\
\text { Agree }\end{array}$ \\
\hline \multirow{2}{*}{$\begin{array}{l}\text { Consumer-Brand } \\
\text { Connection }\end{array}$} & This brand is part of you and who you are? & 1 & 2 & 3 & 4 & 5 & 6 & 7 \\
\hline & I feel personally connected to the brand? & 1 & 2 & 3 & 4 & 5 & 6 & 7 \\
\hline \multirow[b]{2}{*}{ Brand Prominence } & $\begin{array}{l}\text { My thoughts and feelings toward the brand often } \\
\text { automatic, coming to mind seemingly on their own? }\end{array}$ & 1 & 2 & 3 & 4 & 5 & 6 & \\
\hline & $\begin{array}{l}\text { My thoughts and feelings toward the brand come to } \\
\text { me naturally and instantly? }\end{array}$ & 1 & 2 & 3 & 4 & 5 & 6 & 7 \\
\hline \multirow{3}{*}{$\begin{array}{l}\text { Communal-Brand } \\
\text { Connection }\end{array}$} & I really identify with people who use this brand. & 1 & 2 & 3 & 4 & 5 & 6 & 7 \\
\hline & This brand is used by people like me. & 1 & 2 & 3 & 4 & 5 & 6 & 7 \\
\hline & $\begin{array}{l}\text { I feel a deep connection with others who use this } \\
\text { brand. }\end{array}$ & 1 & 2 & 3 & 4 & 5 & 6 & 7 \\
\hline \multirow{3}{*}{$\begin{array}{l}\text { Customer } \\
\text { Commitment }\end{array}$} & $\begin{array}{l}\text { I am willing "to go the extra mile" to work with this } \\
\text { brand. }\end{array}$ & 1 & 2 & 3 & 4 & 5 & 6 & \\
\hline & $\begin{array}{l}\text { I have a desire to maintain my relationship with the } \\
\text { brand. }\end{array}$ & 1 & 2 & 3 & 4 & 5 & 6 & \\
\hline & $\begin{array}{l}\text { I view the relationship with this brand as a long-term } \\
\text { relationship }\end{array}$ & 1 & 2 & 3 & 4 & 5 & 6 & 7 \\
\hline \multirow{3}{*}{$\begin{array}{l}\text { Intention to Spread } \\
\text { Positive Word-of- } \\
\text { Mouth }\end{array}$} & $\begin{array}{l}\text { I would say positive things about this brand to other } \\
\text { people. }\end{array}$ & 1 & 2 & 3 & 4 & 5 & 6 & 7 \\
\hline & $\begin{array}{l}\text { I would recommend this brand to someone who seeks } \\
\text { my advice. }\end{array}$ & 1 & 2 & 3 & 4 & 5 & 6 & 7 \\
\hline & $\begin{array}{l}\text { I would encourage friends and relative to do business } \\
\text { with this brand. }\end{array}$ & 1 & 2 & 3 & 4 & $\mathbf{s}$ & 6 & 2 \\
\hline
\end{tabular}

Figure 2 Brand community member participant screen 


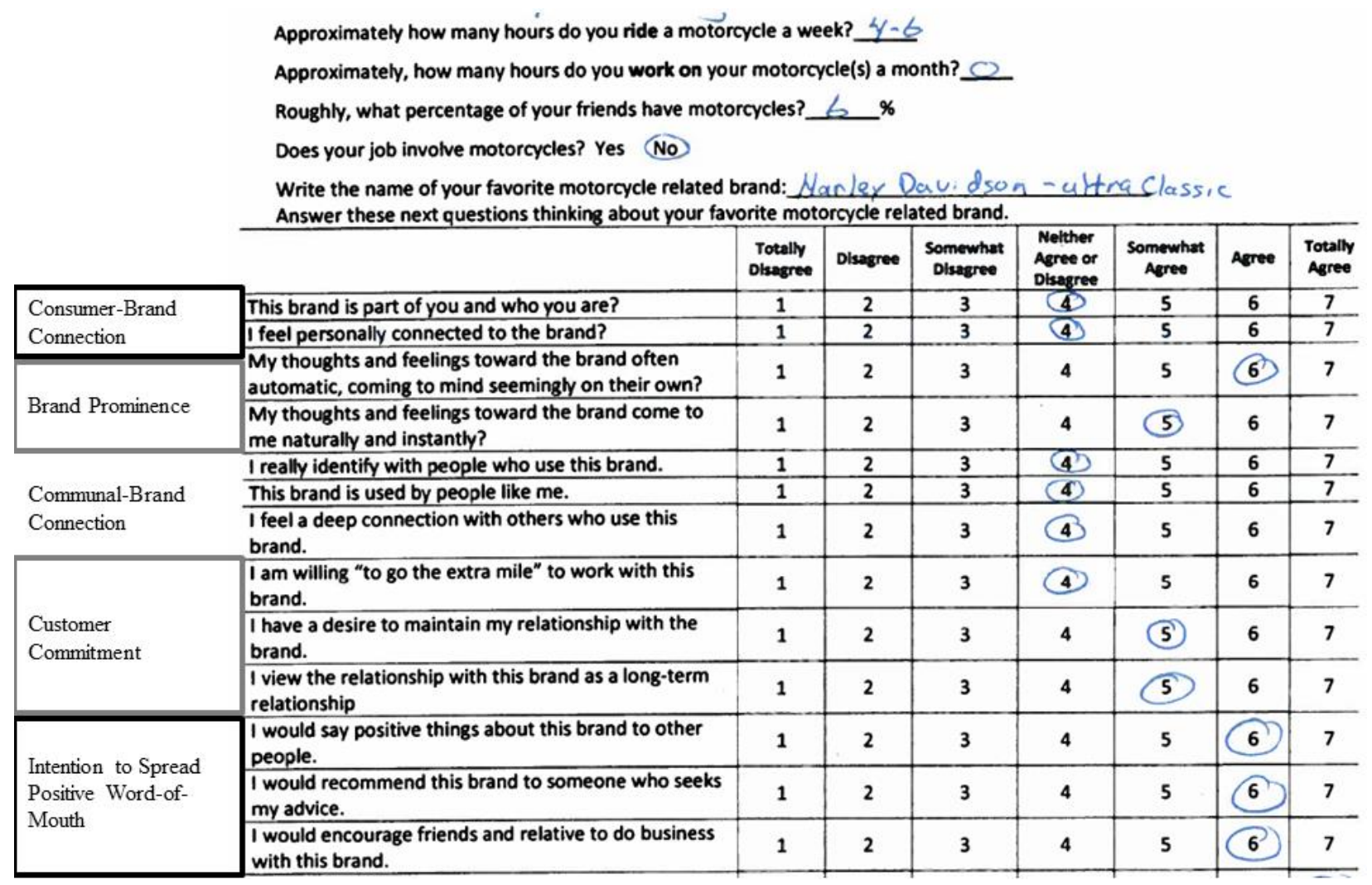

Figure 3 Consumption tribe member participant screen

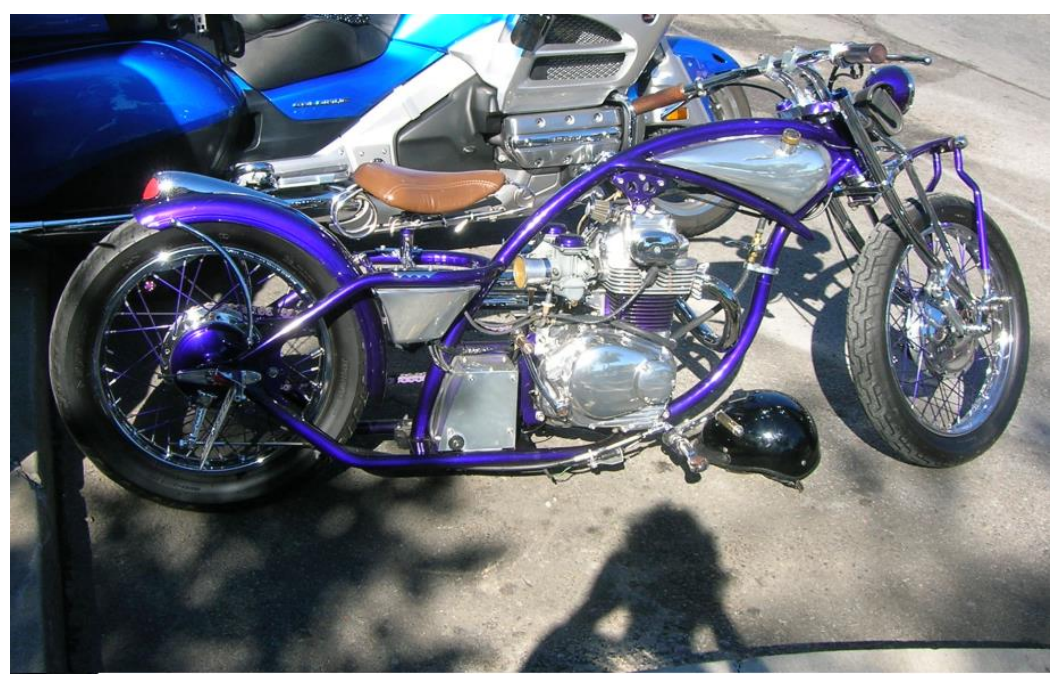

Figure 4 Community of practice motorcycle 


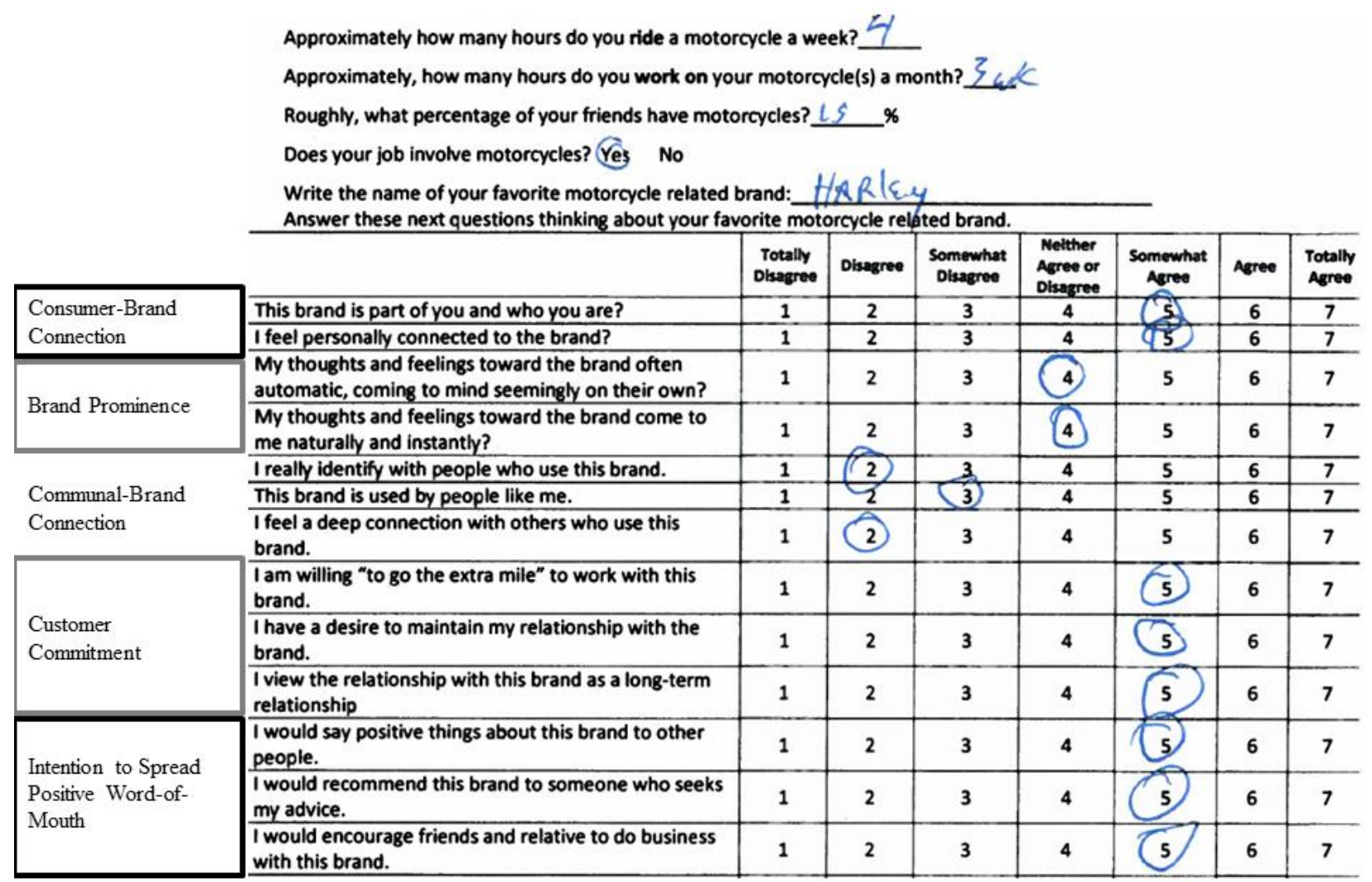

Figure 5 Community of practice member participant screen 


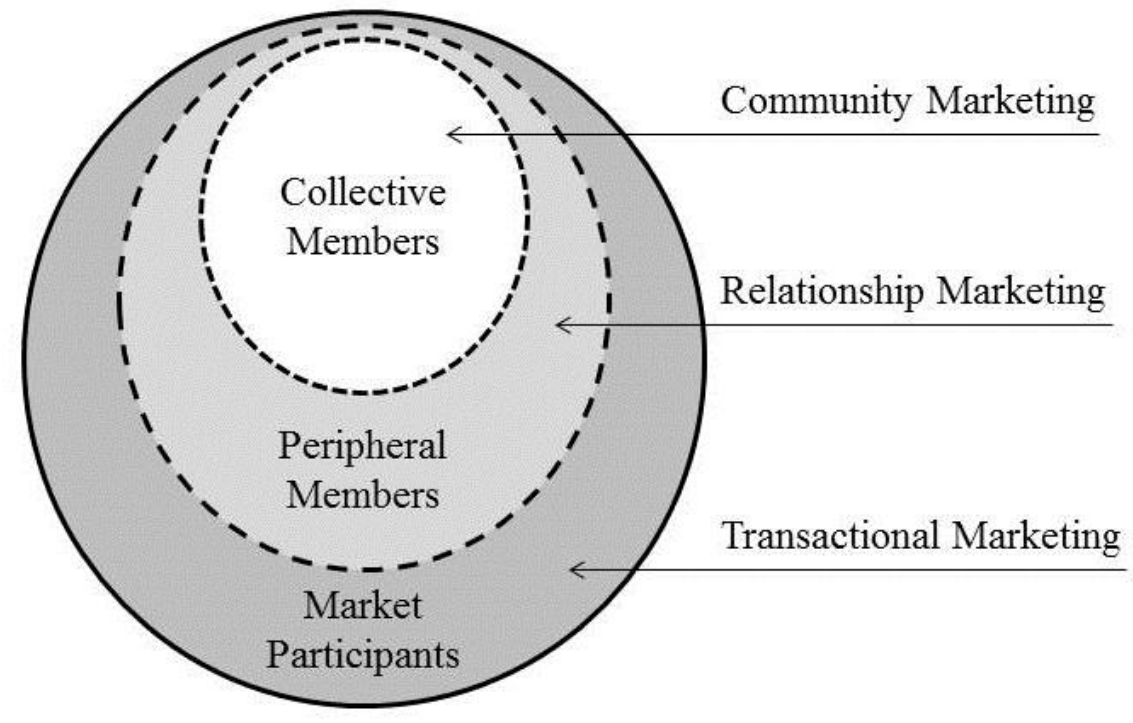

Figure 6 Membership status and marketing strategies 